\title{
CORRECTION
}

\section{Correction to: Medical speciality, medication or skills: key factors of prehospital joint reduction. A prospective, multicenter cohort study}

\author{
Georg Siebenbürger $^{1} \cdot$ Christian Zeckey $^{1} \cdot$ Julian Fürmetz $^{1} \cdot$ Ben Ockert $^{1} \cdot$ Wolfgang Böcker $^{1} \cdot$ Tobias Helfen $^{1}$
}

Published online: 14 March 2018

๑) Springer-Verlag GmbH Germany, part of Springer Nature 2018

\section{Correction to:}

European Journal of Trauma and Emergency Surgery https://doi.org/10.1007/s00068-018-0933-8

The original version of this article unfortunately contained a mistake.

Ben Ockert was not listed among the authors. 